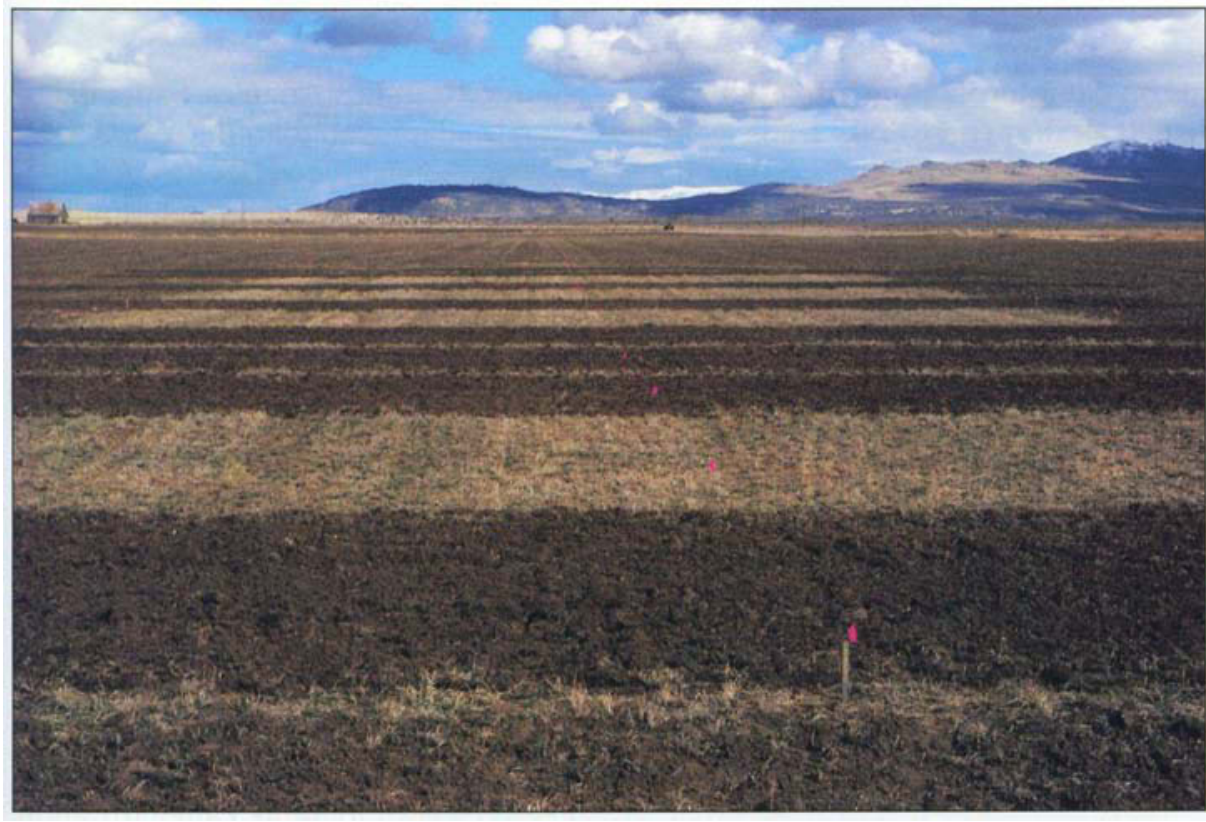

Oats were broadcast in this established alfalfa field and the area disked to bury the seed. The oats emerging in the open gaps prevent weeds from filling in.

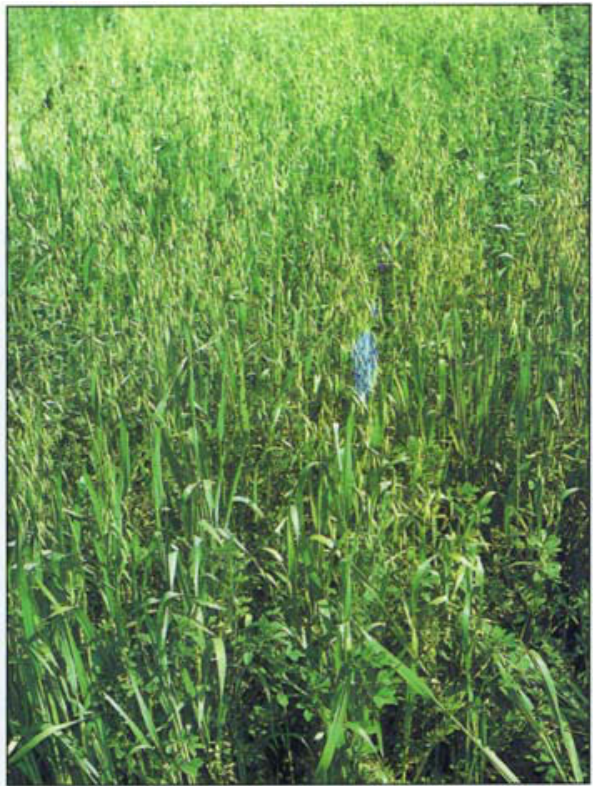

In this mixture of oat and alfalfa in Lassen County, the oats were allowed to partially mature since the hay was sold to the horse market, where some oat grain is desirable.

UCे IPM

\title{
Interplanting grasses into alfalfa controls weeds in older stands
}

\author{
Timothy S. Prather a W. Thomas Lanini $\square$ Steve Orloff $\square$ Ronald Vargas a Jerry L. Schmierer \\ Kurt Hembree a W. Mick Canevari a Shannon Mueller a Warren Bendixen a Rose L. Krebill-Prather
}

\begin{abstract}
Interplanting grasses into alfalfa effectively uses grass competition to reduce the amount of weeds in alfalfa hay. The increased production offsets a lower price for the hay content, making the alfalfa-grass hay equally profitable to alfalfa hay sprayed with herbicide. This technique avoids plant-back restrictions from use of some herbicides. Alfalfa weevil populations can be reduced below threshold levels, providing additional benefit from the technique. The percentage of growers interplanting did not change but nearly half of the $24 \%$ of growers using interplanting are new users of the technique. Cooperative Extension was viewed as the most useful source for interplanting information by $64 \%$ of farmers surveyed.
\end{abstract}

\begin{abstract}
$A^{s}$ $s$ an alfalfa stand declines with age, spaces open up between plants where weeds can invade. Alfalfa stands are usually taken out of production after 3 to 6 years because of declining production or for rotation to another crop. Herbicides can be used to control weeds in thin alfalfa stands, but most herbicides, except for paraquat, limit crop rotation options because of potential rotational crop injury. However, without herbicides, weeds can flourish and become a problem. Weedy hay is discounted $\$ 10$ to $\$ 40$ per ton, and hay infested with fiddleneck (Amsinkia spp.) or common groundsel (Senecio vulgaris) is often unmarketable because these species are poisonous to livestock.

Interplanting grasses during the last year or two of production provides an effective alternative to chemical weed control. Rotational crop op-
\end{abstract}

tions are increased because there are no plant-back restrictions. Hay production can be improved by interplanting grasses, but potential reduction in hay quality may limit marketing the hay to the horse, beef cattle and dry milk-cow markets rather than to the producing dairy market.

Seedbed preparation takes place in December, destroying alfalfa weevil habitat, and may provide additional economic benefit to the farmer because an insecticide application may be avoided, thereby benefiting beneficial insects. Avoiding an insecticide treatment also allays some concerns for water quality in the Sacramento Valley, adding another dimension to the utility of the practice.

\section{Demonstration projects}

In the late 1980 s, we initiated the first Statewide IPM Project-funded tri- 
TABLE 1. Weed cover and forage yield in 1990 at the first cutting (April 25) in established alfalfa, relative to winter weed management at the Gainey Ranch, Santa Ynez, CA

\begin{tabular}{lcc}
\hline \hline Treatment & $\begin{array}{c}\text { Weed } \\
\text { cover }\end{array}$ & $\begin{array}{c}\text { Forage } \\
\text { yield }\end{array}$ \\
\hline & $\%$ & tons/acre \\
Oats seeded @ $50 \mathrm{lb} /$ acre $+\mathrm{N}^{*}$ & 12.5 & 1.64 \\
Paraquat @ $0.5 \mathrm{lb} /$ acre & 18.8 & 0.53 \\
Cultivation alone & 28.8 & 0.92 \\
Untreated & 33.8 & 0.86 \\
LSD & 14.0 & 0.27 \\
\hline
\end{tabular}

*Oats were broadcast seeded and incorporated by cultivation. Nitrogen was added at the rate of $30 \mathrm{lb}$ of nitrogen per acre to oat plots. als on oat interplanting into established alfalfa. These early trials were located in Lassen, Santa Barbara and Los Angeles counties. Initial trials focused on improving forage yields while decreasing weeds. These research projects identified the benefits of interplanting oats.

We established subsequent trials in the 1980 s to demonstrate the benefits of oat interplanting and to explore the use of other forage grasses as potential interplant species. These projects were

TABLE 2. Madera site forage yield and relative proportion of yield for alfalfa, forage grass and weeds

\begin{tabular}{|c|c|c|c|c|c|}
\hline & \multirow{2}{*}{$\frac{\text { Forage yield* }^{*}}{1993}$} & & \multicolumn{3}{|c|}{ Forage composition $\uparrow$} \\
\hline & & & Alfalfa & Grass & Weeds \\
\hline & tons/acre & & \multicolumn{3}{|c|}{ 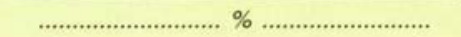 } \\
\hline Tetraploid ryegrass + orchardgrass & 8.5 & & 73 & 25 & 2 \\
\hline Tetraploid ryegrass + tall fescue & 8.5 & & 81 & 18 & 1 \\
\hline Paraquat & 7.8 & . & 100 & 0 & 0 \\
\hline Untreated & 8.4 & & 87 & 0 & 13 \\
\hline $\mathrm{LSD}_{0.05}$ & 0.74 & & 6 & 6 & 6 \\
\hline
\end{tabular}

"Total forage yield for seven cuttings

†Forage composition for the first cutting

TABLE 3. Cost analysis of alfalfa production using four weed management options at the Madera site

\begin{tabular}{|c|c|c|c|c|}
\hline & $\begin{array}{c}\text { Ryegrass + } \\
\text { orchardgrass }\end{array}$ & $\begin{array}{c}\text { Ryegrass + } \\
\text { tall fescue }\end{array}$ & $\begin{array}{l}\text { Paraquat + } \\
\text { diuron }\end{array}$ & $\begin{array}{l}\text { Untreated } \\
\text { control }\end{array}$ \\
\hline & & ............ & ........... & ............. \\
\hline Yield & 8.48 & 8.45 & 7.8 & 8.42 \\
\hline Cultural costs* & 118 & 118 & 150 & 150 \\
\hline Harvest costs & 173 & 173 & 173 & 173 \\
\hline Postharvest costs $\dagger$ & 69 & 52 & 22 & 13 \\
\hline Capital costs & 13 & 13 & 13 & 13 \\
\hline Overhead costs & 516 & 516 & 516 & 516 \\
\hline Gross profit & 941 & 1,000 & 1,010 & 989 \\
\hline Net profit & 52 & 128 & 136 & 88 \\
\hline
\end{tabular}

"Cultural costs do not include insecticide sprays for the interseeded areas because sampling showed that alfalfa weevil was below the treatment threshold.

†Postharvest costs include the cost of seed and planting the grasses, of fertilizer and of herbicide.

$\ddagger$ Price for the alfalfa grass hay for the first two cuttings was discounted $\$ 20 /$ ton, and untreated hay was discounted $\$ 30 /$ ton for two cuttings. All cuttings were discounted $\$ 10$ for the fifth through seventh cuttings because of reduced quality.

TABLE 4. Lancaster site forage yield and composition during two cutting seasons in relation to grass interplanting and paraquat treatment

\begin{tabular}{|c|c|c|c|c|c|c|c|c|}
\hline \multirow[t]{3}{*}{ Treatment $^{*}$} & \multicolumn{2}{|c|}{ Forage yieldt } & \multicolumn{6}{|c|}{ Forage composition $\ddagger$} \\
\hline & \multirow[t]{2}{*}{1992} & \multirow[t]{2}{*}{1993} & \multicolumn{3}{|c|}{1992} & \multicolumn{3}{|c|}{1993} \\
\hline & & & Alfalfa & Grass & Weed & Alfalfa & Grass & Weed \\
\hline & \multicolumn{2}{|c|}{ tons/acre } & ............. & $\cdots$ & … & .......... & $\cdots$ & a...... \\
\hline Tall fescue & 9.30 & 9.33 & 46 & 49 & 4 & 36 & 64 & 0 \\
\hline Orchardgrass & 8.45 & 8.27 & 60 & 37 & 3 & 42 & 56 & 2 \\
\hline Tetraploid ryegrass & 7.96 & 6.62 & 63 & 30 & 7 & 67 & 11 & 21 \\
\hline $\begin{array}{l}\text { Tetraploid ryegrass + } \\
\text { tall fescue }\end{array}$ & 8.98 & 8.45 & 54 & 44 & 2 & 39 & 61 & 0 \\
\hline Paraquat & 8.10 & 7.06 & 84 & 0 & 6 & 73 & 0 & 27 \\
\hline Untreated & 8.49 & 7.09 & 87 & 0 & 13 & 76 & 0 & 24 \\
\hline $\mathrm{LSD}_{0.05}$ & 0.74 & 0.97 & 6 & 6 & 5 & 11 & 9 & 7 \\
\hline
\end{tabular}

- Initial seeding of grasses occurred on Dec. 21, 1991. 'Letar' orchardgrass, 'Fawn' tall fescue, and 'Tetraploid' annual ryegrass were seeded at $20 \mathrm{lb} / \mathrm{acre}$, and both 'Fawn' tall fescue, and 'Tetraploid' annual ryegrass were seeded at $20 \mathrm{lb} /$ acre in the mixture. Paraquat was applied at $0.5 \mathrm{lb}$ ai/acre.

$\uparrow$ Total forage yield for six cuttings in each year

$\ddagger$ Composition of alfalfa, grass and weeds is the average of all harvests. 


\section{Oats displaced weeds}

\begin{abstract}
Research indicates that interplanting mixtures of grasses into alfalfa is an effective and economical alternative to herbicides for weed control (Lanini et al. 1999). Weed reductions of $75 \%$ in the first cutting and $50 \%$ in subsequent cuttings have been achieved when oats were interseeded (Roncoroni and Lanini 1992). These trials showed that oats could displace weeds and were at least as effective as paraquat or cultivation (table 1). First-cutting forage yields were also improved by interplanting oats.
\end{abstract}

Other trials examined oat variety, oat seeding rate, nitrogen rate and oat planting method. Growers experimenting with oat/alfalfa hay were primarily selling to the horse market. Some oat varieties improved forage yields. However, grower experiences quickly pointed to the need for oat varieties to be fine-stemmed and leafy for marketability, such as 'Montezuma.' Oat seeding-rate studies compared rates from $25 \mathrm{lb} / \mathrm{acre}$ up to $100 \mathrm{lb} /$ acre. Forage yields did not increase once seeding rates reached 50 to $75 \mathrm{lb} /$ acre. Higher rates reduced the proportion of alfalfa in the mixture. In one of the first studies conducted, we observed that oats did not improve forage yield in the absence of nitrogen, but that adding small amounts of nitrogen at the time of planting increased oat growth and overall forage yield. Subsequent studies investigated the effect of nitrogen fertilization rate and demonstrated that nitrogen rates over $30 \mathrm{lb} /$ acre are not necessary. Nitrogen timing tests showed that applications made at the time of oat planting are as effective as delayed applications or split applications.

The final study dealt with the method of planting. All of the early tri-

Cultivating this established alfalfa field in Santa Barbara County dislodges established weeds and buries the oat seeds that were broadcast prior to cultivation.

als were established by broadcasting the oat seed and incorporating it with a disk or harrow, attempting to bury the seed 1 to 2 inches deep. We compared this method with a no-till drill. No-till drilling of oats proved to be less effective, because drilling placed oats closer to alfalfa crowns, making less efficient use of open spaces, compared to broadcasting of oats.

\section{Plant combinations effective}

Results from the Madera sites indicated that interplanting combinations of tetraploid annual ryegrass and either orchardgrass or tall fescue reduced weeds. Weeds in forage were $0 \%$ to $2 \%$ of the hay yield for interplanted or herbicide-treated alfalfa, and $13 \%$ of hay yield in the untreated alfalfa (table 2). Weeds persisted into the second cutting only in untreated hay. Weeds did not persist after the second cutting.

Total production for the season was significantly lower from the herbicidetreated plots than from all other treatments (table 2). The lower total yield was because of significantly lower yields in the first and second cuttings (fig. 1). Hay from the ryegrass + orchardgrass plots yielded 1.8 times more forage $(2,856 \mathrm{lb} /$ acre versus $1,548 \mathrm{lb} /$ acre) than the alfalfa hay treated with herbicide at the first cutting. The ryegrass + tall fescue combination had the highest second-cutting yield, 1.2 times higher than the herbicide-treated alfalfa $(3,223 \mathrm{lb} /$ acre versus $2,676 \mathrm{lb} / \mathrm{acre}$ ) at the second cutting.

The price for hay from the untreated plots and from interplanted plots was discounted $\$ 10 /$ acre to $\$ 30$ / acre because of weeds or grasses (table 3 ). The alfalfa stand was very healthy, and only the first two cuttings contained weeds. Ryegrass was a component of yield for the first two cuttings, ranging from $44 \%$ to $46 \%$ and from $19 \%$ to $30 \%$, respectively. Grass production declined after the second cutting and did not contribute to yield. Cost analysis of these treatments showed the highest profit for the herbicide-treated hay and for the 


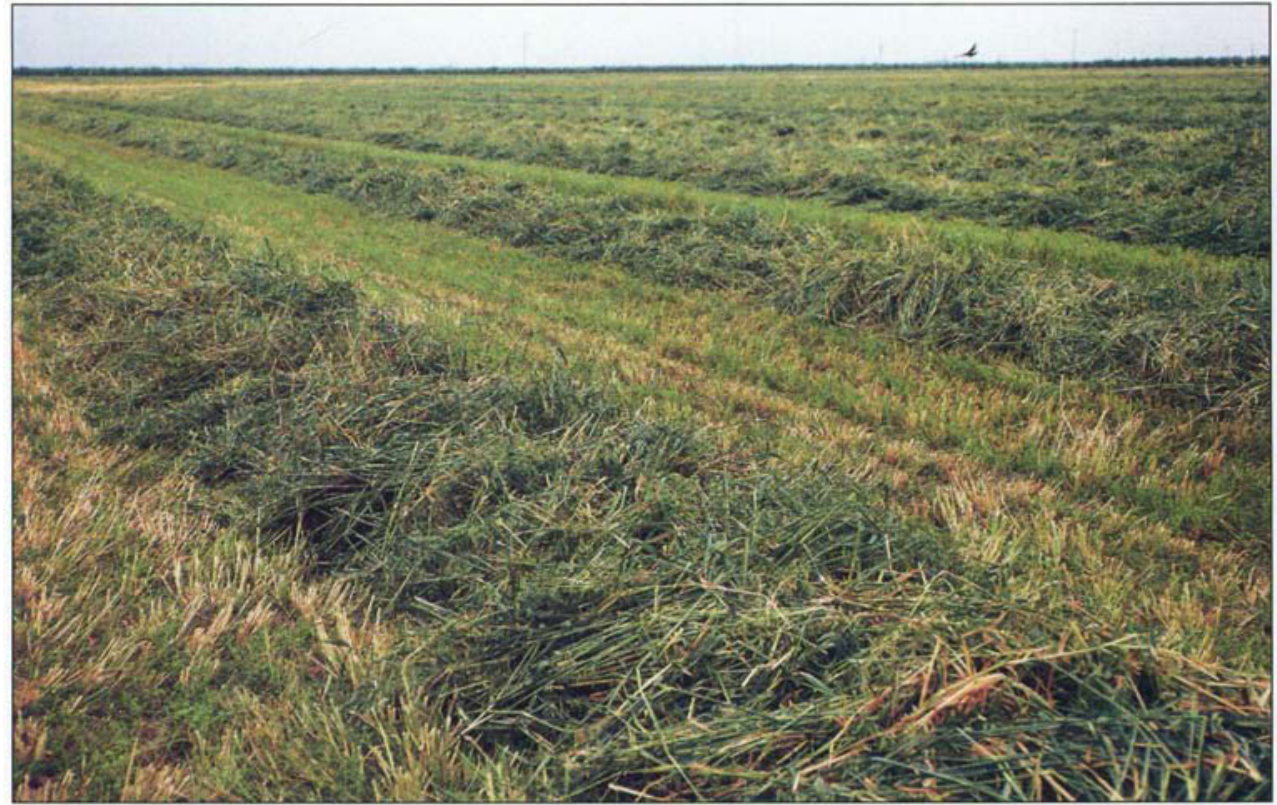

Weed reductions of $\mathbf{7 5 \%}$ in the first cutting and $\mathbf{5 0 \%}$ in subsequent cuttings have been achieved in fields where oats were interseeded.

ryegrass + fescue hay (table 3 ). The annual ryegrass was gone after the second cutting, and the tall fescue was not a component of yield, so the hay was given a premium price after the second cutting. The alfalfa treated with herbicide received a premium

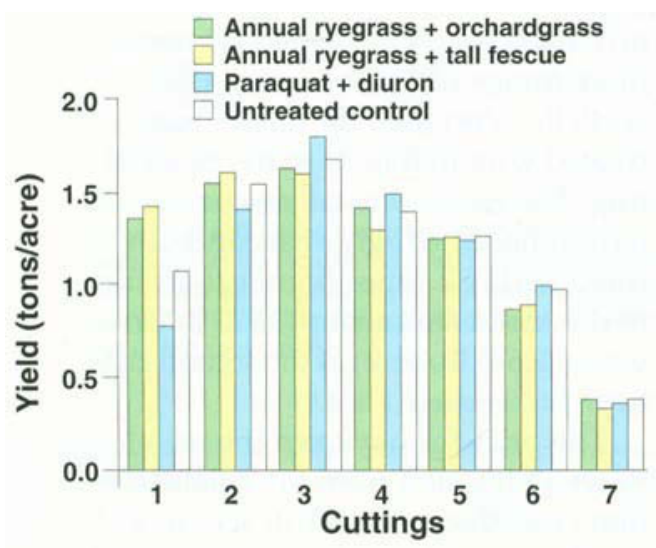

Fig. 1. Alfalfa yield at each harvest from treatments consisting of tetraploid annual ryegrass + orchardgrass, tetraploid annual ryegrass + tall fescue, paraquat/diuron application or untreated control. Mean comparisons were made between treatments of the same cutting. No comparisons were made between cuttings. Bars within the same cutting with the same letter are not statistically different. Protected LSD values for each cutting were: (1) LSD $=0.35$; (2) LSD $=0.08$; (3) LSD $=0.10$; (4) LSD = $0.09 ;(5)$ LSD $=0.12 ;(6)$ LSD $=0.11 ;$ and $(7)$ LSD $=0.10$. price, but decreased yield reduced the net profit. The orchardgrass persisted through all cuttings, resulting in a discounted price applied to alfalfa for all cuttings.

Although the annual ryegrass + orchardgrass treatment was successful in maintaining a grass through the season, it had the smallest profit margin. If the alfalfa stand had been older and therefore weedier (this particular producer took alfalfa out after 3 years), the addition of orchardgrass might have reduced the discount on weedy hay. The economics are different in foothill areas than in mountain areas because roughly $50 \%$ of the total production is from the first cutting. Economic analysis of hay production in Susanville demonstrates higher gross income of $\$ 649$ per acre for alfalfa grass mixture, $\$ 615$ per acre for weed-free hay and $\$ 523$ for hay that is weedy at the first cutting.

\section{Yields increase in second year}

Although the use of perennial grasses may have limited value during the year they are seeded, we examined their impact when left for a second year. This study was established near Lancaster, in Los Angeles County, in a relatively weedy, 7-year old alfalfa stand. Yields in the first year were comparable to what was observed in the Madera study (fig. 1), with a small increase in yield when perennial grasses were interplanted compared to the herbicide treatment (table 4). Forage yields in the second year were increased by 1 to 2 tons/acre in the second year, when perennial forages were interplanted compared to untreated alfalfa. The relative proportion of alfalfa and weeds in both cutting years was reduced by interplanting perennial grasses (data not shown). The perennial grasses made up less than $50 \%$ of the forage in the first year but over $50 \%$ in the second. Perennial grasses were slow to establish and did not add much forage to the first few cuttings at this location, but by the second year were growing much more vigorously and provided more of the total forage.

Interplanting grass mixtures into alfalfa was shown to decrease alfalfa weevil damage (Bendixen and Lanini 1993). At a Madera County site, alfalfa weevil populations were 4 or 5 per sweep in the plots that were interplanted in December versus 18 per sweep (populations at the threshold level) in plots that were not interplanted. In a subsequent experiment, 3-acre plots were either left untreated, cultivated, or cultivated and interplanted in late December. Alfalfa weevil populations were lower in the cultivated or cultivated and interplanted plots than in the untreated plots (fig. 2). Any reduction in population of alfalfa weevils resulting in less insecti-

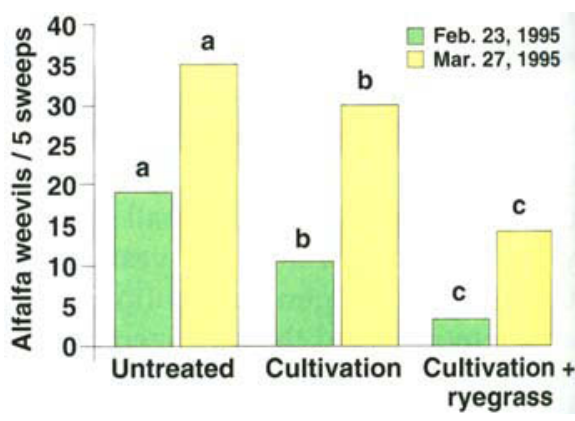

Fig. 2. Cultivation and planting during Docember reduced alfalfa weevil larval populations in late February 1995. Bars labeled with the same letter at each sample date are not significantly different $\left(\mathbf{L S D}_{0.05}=\right.$ 1.41). 
cidal treatment would be helpful in preventing disruption of beneficial insects.

\section{Growers aware of interplanting}

Our 1993 survey of Fresno County and Madera County alfalfa growers $(70 \%$ response rate) indicated that $24 \%$ of the farmers had used interplanting. Another $31 \%$ of farmers did not interplant but were familiar with the practice, and the remaining $45 \%$ had not heard of the practice. Of those familiar with the practice, $39 \%$ first heard about it from other farmers and $29 \%$ listed a UC information source. Of those farmers who interplant, $39 \%$ indicated that other farmers
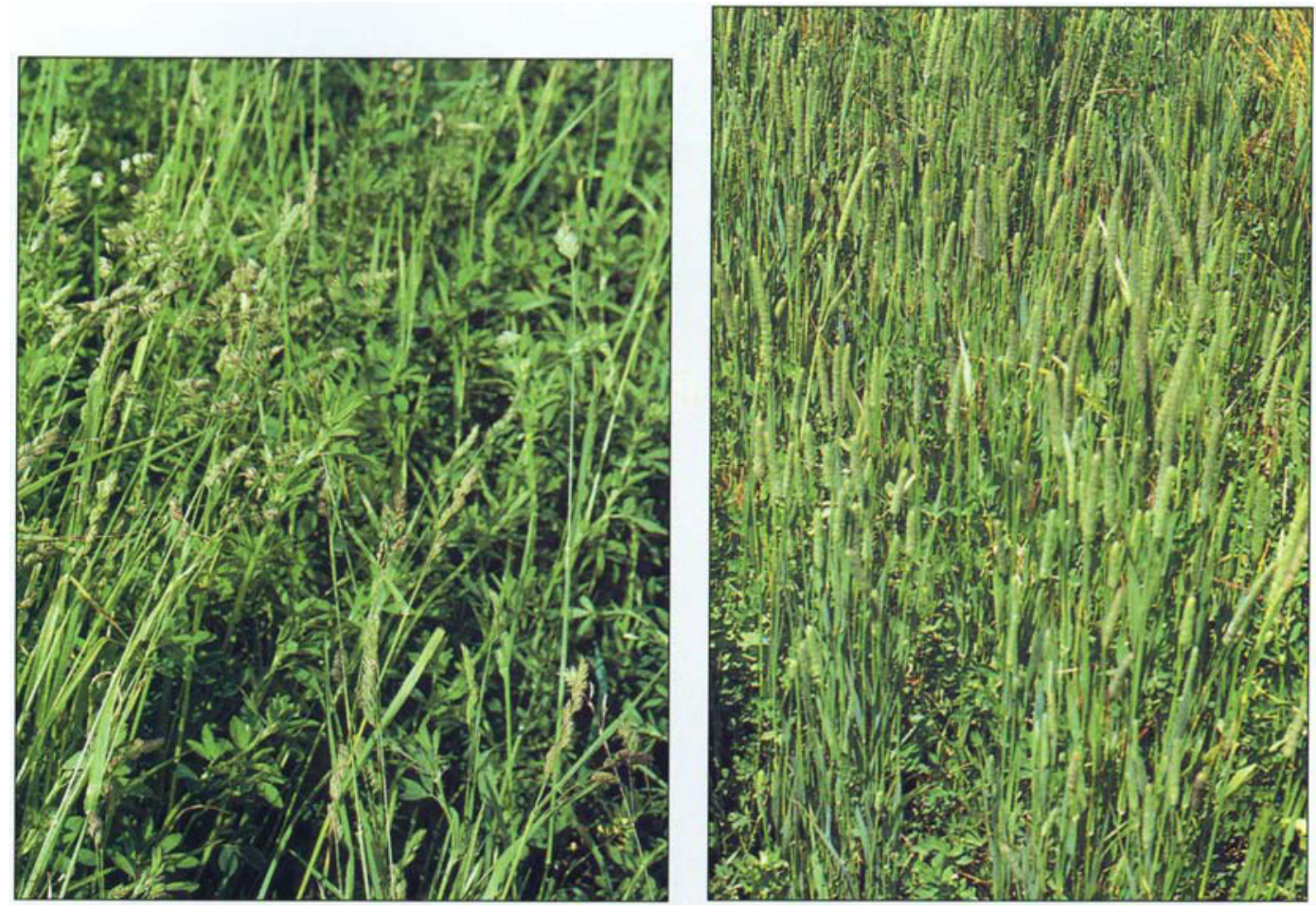
were their most useful source of information on interplanting and another $36 \%$ listed a UCCE-developed information source (table 5). At the conclusion of the Smith-Lever project, when growers were contacted again, the same percentage of farmers used the practice $(24 \%)$, so no increase in adoption was realized (table 5). However, $45 \%$ of current users were new to the practice since the Smith-Lever project started in 1993.

Overall, more farmers are aware of the practice, with an additional $17 \%$ more farmers familiar with the practice (table 5). By the conclusion of the project, $10 \%$ fewer farmers relied on other farmers for useful information
Orchardgrass, a cool-season perennlal grass, is commonly interseeded into alfalfa in some areas and is in high demand by the horse industry.

(29\%), and there was a $28 \%$ increase in the number reporting a UCCEdeveloped information source as the most useful $(64 \%)$. An additional $18 \%$ stated that a trade journal contained the most useful information, which probably reflected the September 1993 article in California-Arizona Farm Press about the Smith-Lever project.

T.S. Prather is Assistant Professor and Extension Specialist, Weed Ecology, Department of Plant, Soil and Entomological

TABLE 5. Use of interplanting, knowledge of interplanting and useful sources of information on interplanting from surveys of Fresno and Madera growers

\begin{tabular}{llcc}
\hline \hline Subject & & $\begin{array}{c}\text { Pretest } \\
1993\end{array}$ & $\begin{array}{c}\text { Post-test } \\
2000\end{array}$ \\
\hline Use interplanting & & $24 \%$ & $24 \%^{*}$ \\
Nonuser familiarity with practice & Not familiar & $45 \%$ & $28 \%$ \\
& Familiar & $31 \%$ & $48 \%$ \\
First heard of practice & & $\mathrm{N}=123$ & $\mathrm{~N}=58$ \\
& Another grower & $39 \%$ & $26 \%$ \\
& UC source & $29 \%$ & $44 \%$ \\
User's best information source & Other & $32 \%$ & $30 \%$ \\
& & $\mathrm{~N}=68$ & $\mathrm{~N}=42$ \\
& Another grower & $39 \%$ & $29 \%$ \\
& UC source & $36 \%$ & $64 \%$ \\
& Other & $25 \%$ & $7 \%$ \\
\end{tabular}

"Nearly half $(45 \%)$ of the users began interplanting after the Smith-Lever project was initiated.

Mixed stands of alfalfe and timothy are much less common than orchardgrass and alfalfa because timothy is more difficult to establish, is generally lower ylelding, and has more specific environmental requirements.

Sciences, University of Idaho, Moscow, and former UC IPM Weed Ecologist, Statewide IPM Project; W.T. Lanini is CE Weed Ecologist, Department of Vegetable Crops, UC Davis; R. Vargas is County Director and Farm Advisor, Madera County; S. Orloff, W.M. Canevari, K. Hembree, S. Mueller and W. Bendixen are Farm Advisors, Siskiyou, San Joaquin, Fresno, Fresno and Santa Barbara counties, respectively; I.L. Schmierer is Agronomy Farm Advisor, Colusa County; and R.L. Krebill-Prather is Sociologist, Statewide IPM Project, UC Davis.

\section{References}

Bendixen WE, Lanini WT. 1993. Interplanting cereals and grasses during the last year of an alfalfa stand. In Proc. Calif. Weed Conf. Fremont, CA. p 93-101.

Lanini WT, Orloff SB, Bendixen WE, et al. 1999. Influence of oat (Avena sativa) interseeding on weed suppression in the final year of an alfalfa (Medicago sativa) stand. Weed Technol 13(2):399-403.

Roncoroni EA, Lanini WT. 1992. Influence of grass interseeding on weed suppression in the final year of an alfalfa stand. In Proc. Calif. Weed Conf. Fremont, CA. p 13. . 